\title{
On the mechanical behavior of an Al 7075 alloy deformed by asymmetrical and conventional rolling
}

\author{
Matheus Garcia do Vale ${ }^{1}$, Neil de Medeiros ${ }^{1}$, Gláucio Soares da Fonseca ${ }^{1}$ \\ Saulo Brinco Diniz ${ }^{2}$, Andersan dos Santos Paula ${ }^{2}$, \\ Luiz Paulo Mendonça Brandão ${ }^{2}$
}

\footnotetext{
${ }^{1}$ Universidade Federal Fluminense, CEP: 27255-125, Volta Redonda, Rio de Janeiro, Brazil.

${ }^{2}$ Instituto Militar de Engeharia, CEP: 22290-270, Rio de Janeiro, Rio de Janeiro, Brazil. e-mail: matheusgv2@hotmail.com,neil@metal.eeimvr.uff.br, glaucio@metal.eeimvr.uff.br, saulo_brinco@hotmail.com; andersan@ime.eb.br; brandao@ime.eb.br
}

\section{ABSTRACT}

Samples of the Al 7075 naturally and artificially aged were processed by conventional and asymmetrical rolling with $5 \%$ of thickness reduction. The rolling processes were evaluated under room temperature and under warm condition $\left(130^{\circ} \mathrm{C}\right)$. Mechanical properties were evaluated by uniaxial tensile and Vickers microhardness tests. Microstructure evolutions were followed by optical microscopy analysis. Naturally aged samples showed better yield strengthening under warm processing. Greater ultimate stress and ductility under room temperature processing was also noticed in naturally aged specimens. Artificially aged samples showed better mechanical properties under room temperature, softening under warm processing due to grain recovery process. Microhardness tests showed expected results for both rolling types, especially on asymmetrical rolling with the higher predictions were observed. Micrographs have shown no expressive grain changes or refinement although its flattening was observed. Precipitates were analyzed by EDS/SEM revealing the presence of $\mathrm{MgZn}_{2}$ and $\mathrm{CuMgAl}$ along the matrix that provides plastic strengthening.

Keywords: Aging, asymmetrical rolling, conventional rolling, mechanical behavior, Al 7075 alloy.

\section{INTRODUCTION}

Studies about Severe Plastic Deformation, SPD, processes were introduced by Percy W. Bridgman from investigations of material processing through a combination of loads [1,2]. Bridgman received the Nobel Prize of physics in 1946 for his studies about the effects of high pressure on materials [3]. Then, other material processing techniques were developed in the area such as accumulative roll bonding, ARB [4], equal-channel angular pressing, ECAP [4-6], asymmetrical rolling, ASR [7-11], among others. Severe processes are used to refine materials grains [4,12-14] providing better mechanical properties to materials and improving its texture $[10,15]$.

Aeronautical Al 7075 alloy is known by its high strength capabilities allied to low mass density. Its strengthening is directly associated with hardening due to heat treatments which lead to formation of small precipitates responsible to prevent dislocations motion and, thus, improve its mechanical properties [16]. Also, for Al 7075 alloy, natural aging is observed after solution heat treatment and, consequently, important variations of material hardness can be obtained. The proof of room temperature hardening phenomenon was proposed by Guinier and Preston [20] by demonstrating that small clusters of solute that was named as Guinier-Preston zone or just G-P zone. For Al 7075 alloy, a metastable $\eta$ ' phase and a stable $\eta$ phase, composed by $\mathrm{MgZn}_{2}$ and $\mathrm{CuMgAl}$ precipitate clusters were discovered in temperatures between $100-180^{\circ} \mathrm{C}$ [17]. These precipitate clusters can also have its precipitation kinetics improved by mechanical treatment [17]. Another heat treatment employable to the $\mathrm{Al} 7075$ is artificial aging that starts when the precipitation kinetics is favored with samples heating in furnace at $120^{\circ} \mathrm{C}$.

Some previous works were focused on the application of ASR in different materials with satisfactory results to magnesium alloys [18]. Also, with pure aluminum, reaching greater strength and hardness values [19]. Aluminum of $6 \times x x$ series was also analyzed comparing ASR and conventional rolling, CR, processes with its thickness reduction based on different velocity ratios [10,20-21] having an improvement on its 
mechanical properties and texture. Different diameter, velocity and friction ratios were studied on ASR reaching better formability and less strengthening in case of different diameter ratio due to texture changes [15]. Annealed 7075 aluminum alloy was submitted to asymmetrical and conventional rolling with different roll velocities varying its entry routes to compare the mechanical strengthening response [22].

Into this context, the present work is aimed at compare the mechanical behavior, proposing a combination of a dynamic thermomechanical interaction in the process, of an $\mathrm{Al} 7075$ slightly hardened at room temperature by natural aging, $\mathrm{T} 4$, and an already hardened by precipitation after artificial aging treatment, T651. The mechanical process was evaluated by CR and ASR under a thickness reduction of 5\% in one only pass at room temperature and $130^{\circ} \mathrm{C}$, with the intention of completely precipitating any available solute. To evaluate the mechanical properties, uniaxial tensile test and microhardness tests were performed in order to investigate the influence of ASR and CR over the Al 7075 alloys. To follow the grain evolution toward the processes, the microstructure was observed through micrographs and analyzed qualitatively.

\section{MATERIALS AND METHODS}

\subsection{Material}

The experimental procedure was applied on an Al 7075 alloy that was received in the T651 condition, and it was acquired from Artisa Metais in the form of plates with dimensions of 1000x1000x20mm. Specimens were machined to sheets with $150 \mathrm{~mm}$ (width) $\mathrm{x} 75 \mathrm{~mm}$ (height) $\mathrm{x} 8 \mathrm{~mm}$ (thickness). Half of these specimens were undergone to natural aging treatment, termed as $\mathrm{T} 4$, which was obtained after complete annealing followed by solution heat treatment. Annealing treatment was reached after material heating at $415^{\circ} \mathrm{C}$ for 2 hours and subsequent cooling at a rate of $28^{\circ} \mathrm{C} / \mathrm{h}$ until stabilization at $230^{\circ} \mathrm{C}$ after 6 hours. Then, the material was cooled to room temperature inside furnace. Afterwards, to obtain a complete $\mathrm{T} 4$ heat treatment, these annealed samples were heated at $480^{\circ} \mathrm{C}$ for 70 minutes followed by quenching in water. By performing Vickers microhardness tests, which employed procedure is detailed as it follows, it was observed that after for 72 hours at room temperature, the material could be deformed by the rolling processes considered in the present work. The melting temperature for the $\mathrm{Al} 7075$ alloy is $477^{\circ} \mathrm{C}-635^{\circ} \mathrm{C}$ [23]. Table 1 presents the $\mathrm{Al}$ 7075-T651 chemical composition obtained by optical emission spectroscopy performed in an Oxford Instruments model Foundry Master Pro Spectrometer at the Centro de Tecnologia SENAI Solda Maracanã.

Table 1: Chemical composition of Al 7075 alloy (in mass fraction, \%).

\begin{tabular}{c|c|c|c|c|c|c|c|c|c}
\hline $\mathbf{A l}$ & $\mathbf{Z n}$ & $\mathbf{M g}$ & $\mathbf{C u}$ & $\mathbf{F e}$ & $\mathbf{C r}$ & $\mathbf{S i}$ & $\mathbf{M n}$ & $\mathbf{T i}$ & OTHERS (TOTAL) \\
\hline 90.100 & 5.520 & 2.290 & 1.410 & 0.209 & 0.203 & 0.120 & 0.0473 & 0.0208 & 0.0799 \\
\hline
\end{tabular}

\subsection{Methods}

Rolling processes were performed in a FENN MFG. Co., D-51710:1973 model rolling mill available at the Instituto Militar de Engenharia placed at Rio de Janeiro, Brazil. This used rolling mill can be used for two configurations, that is, two-high mill (used for conventional rolling) and four-high mill (used for asymmetrical rolling). The first type employs two working rolls (top and bottom) with the same working conditions (diameter, angular velocity and friction coefficient between roll and specimen) and the second one uses two smaller working rolls with $\sim 1.7$ diameter ratio and two more backups rolls.

The rolling tests were performed at room temperature $\left(24^{\circ} \mathrm{C}\right)$ and $130^{\circ} \mathrm{C}$. For the warm rolling, a preheating of $130^{\circ} \mathrm{C}$ was induced on the specimens for 5 minutes using a furnace located near to the rolling mill. The surface specimen temperatures were manually controlled by a FLUKE 59MAX infrared thermometer. Each processed sample reached a 5\% in thickness reduction after one rolling pass. Greater thickness reductions in one pass were tempted under room temperature (most severe condition) but did not succeed for ASR due to its high load severities.

Main mechanical properties were obtained with uniaxial tensile test with an Instron 100kN universal testing machine 8801 model using a $25 \mathrm{~mm}$ extensometer at room temperature. Three subsize-type samples were machined with $25 \mathrm{~mm}$ of useful length from each processed plate at $0^{\circ}$ of angular orientation with 
respect to the rolling direction according to ASTM E8M [24]. Tests were evaluated under a constant nominal strain-rate of $\sim 10^{-3} \mathrm{~s}^{-1}$. The T4 specimens were rolled after 14 that were aged. The yield stress was defined by the $0.2 \%$ plastic-strain offset method. True plastic stress-strain curves were fitted applying the Swift power law as shown in Equation 1.

$$
\sigma=\mathrm{K}\left(\varepsilon_{0}+\varepsilon\right)^{\mathrm{n}}
$$

where $\mathrm{K}$ is the strength coefficient, $\varepsilon_{0}$ denotes the pre-strain and $\mathrm{n}$ is the strain-hardening exponent.

Mechanical behavior of Al 7075 alloy was also evaluated from Vickers microhardness tests. Before and after rolling, a total of 32 indentations (16 indentations on each plane analyzed) were done along the thickness. Each indentation was done with a load of $980.7 \mathrm{mN}$ that was applied for 20 seconds. The microindentation tests were evaluated on TD (transverse direction) x ND (normal direction) plane and on RD (rolling direction) x ND (normal direction) plane. All of the microindentation experimental procedures were based on ASTM E384 [25] standard norm.

Microstructures were observed along TDxND. Grain boundaries were identified after the surface cleaning from scratches using sandpapers of silicon carbide (P320, P600, P1200 and P2500 mesh), electrolytic polishing (methanol, perchloric acid and ethylene glycol solution) and Keller's etching solution immersion. Micrographs were done using traditional optical microscopic techniques from a Nikon Eclipse LV150 microscope and a NIS-Elements D 3.2 image acquisition software. Then the samples were submitted to SEM (scanning electron microscope) in the Secondary Electrons mode (SE), EVO model MA10 of the manufacturer Carl ZEISS with $\mathrm{LaB}_{6}$. In order to detect the present components, analysis by dispersive energy spectroscopy (EDS) were obtained using the same microscope with an EDS/EBSD integrated system model Pegasus MX4i from EDAX. All of the SEM/EDS analysis was done on NDxTD plane.

\section{RESULTS AND DISCUSSION}

Results obtained from uniaxial tensile tests results are listed in Table 2. It can be seen the average predictions of the yield stress, $\sigma_{\mathrm{y}}$, elastic modulus, $\mathrm{E}$, ultimate tensile strength, $\sigma_{\mathrm{u}}$ and uniform elongation, $\Delta \mathrm{l}_{\mathrm{u}}$. Table 3 shows the plastic parameters $\mathrm{K}, \varepsilon_{0}$ and $\mathrm{n}$ obtained after fitting with Swift power law.

As previously related, the $\mathrm{T} 4$ samples showed themselves more resistant in yield at $130^{\circ} \mathrm{C}$, however, room temperature specimens have become able to deform longer up to a higher ultimate stress, $73 \%$, in $\mathrm{T} 4$ symmetrical room temperature rolled case even under low reduction percentage per pass

In T651 specimens, which $\eta$ phase is already fully precipitated, the warm process softened the material on both rolling types reducing its yield and ultimate stress. In this case, the aging temperature does not improve the results as much as naturally aged does. The softening happens probably because of grains textures changes as mentioned by Lapovok et al. [15] combined to the process of grain recovery.

Table 2: Mechanical properties.

\begin{tabular}{c|c|c|c|c|c|c}
\hline $\begin{array}{c}\text { HEAT } \\
\text { TREATMENT }\end{array}$ & $\begin{array}{c}\text { ROLLING } \\
\text { TEMPERATURE } \\
\left({ }^{\circ} \mathbf{C}\right)\end{array}$ & $\begin{array}{c}\text { ROLLING } \\
\text { TYPE }\end{array}$ & $\begin{array}{c}\sigma_{\mathbf{Y}}{ }^{0.2 \%} \\
(\mathbf{M P A})\end{array}$ & $\begin{array}{c}\text { ELASTIC } \\
\text { MODULUS } \\
(\mathbf{G P a})\end{array}$ & $\begin{array}{c}\sigma_{U} \\
(\mathbf{M P A})\end{array}$ & $\boldsymbol{\Delta l}_{\mathbf{U}}(\%)$ \\
\hline $\mathrm{T} 4$ & - & - & $352 \pm 4.6$ & 72 & 695 & $25 \pm 0.7$ \\
\hline $\mathrm{T} 4$ & 24 & Symmetrical & $440 \pm 5.2$ & 70 & 643 & $17 \pm 0.5$ \\
\hline $\mathrm{T} 4$ & 130 & Symmetrical & $471 \pm 6.1$ & 70 & 604 & $14 \pm 0.2$ \\
\hline $\mathrm{T} 4$ & 24 & Asymmetrical & $433 \pm 8.5$ & 70 & 648 & $19 \pm 0.3$ \\
\hline $\mathrm{T} 4$ & 130 & Asymmetrical & $483 \pm 18.9$ & 72 & 602 & $11 \pm 1.0$ \\
\hline $\mathrm{T} 651$ & - & - & $508 \pm 4.2$ & 69 & 649 & $16 \pm 1.5$ \\
\hline $\mathrm{T} 651$ & 24 & Symmetrical & $551 \pm 6.1$ & 70 & 636 & $10 \pm 1.7$ \\
\hline $\mathrm{T} 651$ & 130 & Symmetrical & $492 \pm 3.5$ & 67 & 597 & $12 \pm 1.4$ \\
\hline $\mathrm{T} 651$ & 24 & Asymmetrical & $496 \pm 4.0$ & 72 & 618 & $12 \pm 1.6$ \\
\hline
\end{tabular}




\begin{tabular}{c|c|c|c|c|c|c}
\hline T651 & 130 & Asymmetrical & $469 \pm 4.9$ & 67 & 591 & $13 \pm 1.5$ \\
\hline
\end{tabular}

An analysis of the results presented in Table 2 and Figure 1 makes clear that the yield stress substantially increases in T4 specimens, especially when it was rolled at $130^{\circ} \mathrm{C}$, closed to its corresponding value with minimum difference of $2.8 \%$ while it was $12 \%$ at room temperature, both after asymmetrical rolling.

From Tables 2 and 3 and Fig. 1 it can be seen the result about the as-received T4 that doubled its yield stress up to the ultimate stress with the greatest elongation among all the others possibilities. Even more, the $\mathrm{K}$-value shows this plastic capability of strengthening along with the hardening coefficient, $\mathrm{K}$.

Table 3 lists the material Vickers hardness obtained values. The symmetrical rolled samples presented highest values on the surfaces in contact with the work rolls, in the same magnitude, decreasing towards the center. However, asymmetrically rolled samples showed different values between top and bottom surfaces with a highest value on the surface in contact with the smaller work roll. These increased values of hardness occurred in the zone near to the contact surface. This fact is due to the different arc of contact between the sample and the working roll on asymmetric process $[10,26]$ imposing different combined loads to the surface.

Table 3: Fitted plastic parameters and average Vickers microhardness.

\begin{tabular}{|c|c|c|c|c|c|c|}
\hline \multirow{2}{*}{$\begin{array}{c}\text { HEAT } \\
\text { TREATMENT }\end{array}$} & \multirow{2}{*}{$\begin{array}{c}\text { ROLLING } \\
\text { TEMPERATURE } \\
\left({ }^{\circ} \mathrm{C}\right)\end{array}$} & \multirow{2}{*}{$\begin{array}{l}\text { ROLLING } \\
\text { TYPE }\end{array}$} & \multicolumn{3}{|c|}{ SWIFT } & \multirow{2}{*}{$\begin{array}{c}\text { VICKERS } \\
\text { MICROHARDNESS } \\
(\mathrm{HV})\end{array}$} \\
\hline & & & $\begin{array}{c}\mathbf{K} \\
(\mathbf{M P a})\end{array}$ & $\varepsilon_{0}$ & n & \\
\hline $\mathrm{T} 4$ & - & - & 1027 & 0.03688 & 0.31 & $141 \pm 10$ \\
\hline $\mathrm{T} 4$ & 24 & Symmetrical & 871 & 0.02259 & 0.18 & $167 \pm 10$ \\
\hline $\mathrm{T} 4$ & 130 & Symmetrical & 686 & 0.00298 & 0.07 & $167 \pm 11$ \\
\hline $\mathrm{T} 4$ & 24 & Asymmetrical & 876 & 0.01941 & 0.18 & $164 \pm 7$ \\
\hline $\mathrm{T} 4$ & 130 & Asymmetrical & 664 & 0.00005 & 0.06 & $171 \pm 8$ \\
\hline $\mathrm{T} 651$ & - & - & 791 & 0.01669 & 0.11 & $174 \pm 3$ \\
\hline T651 & 24 & Symmetrical & 694 & 0.00030 & 0.04 & $173 \pm 10$ \\
\hline T651 & 130 & Symmetrical & 666 & 0.00078 & 0.05 & $170 \pm 8$ \\
\hline T651 & 24 & Asymmetrical & 700 & 0.00121 & 0.06 & $167 \pm 10$ \\
\hline T651 & 130 & Asymmetrical & 671 & 0.00133 & 0.06 & $166 \pm 9$ \\
\hline
\end{tabular}

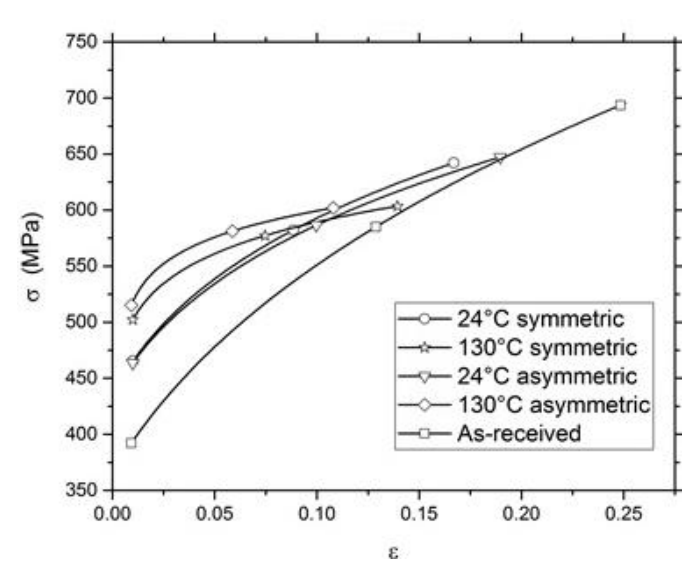

(a)

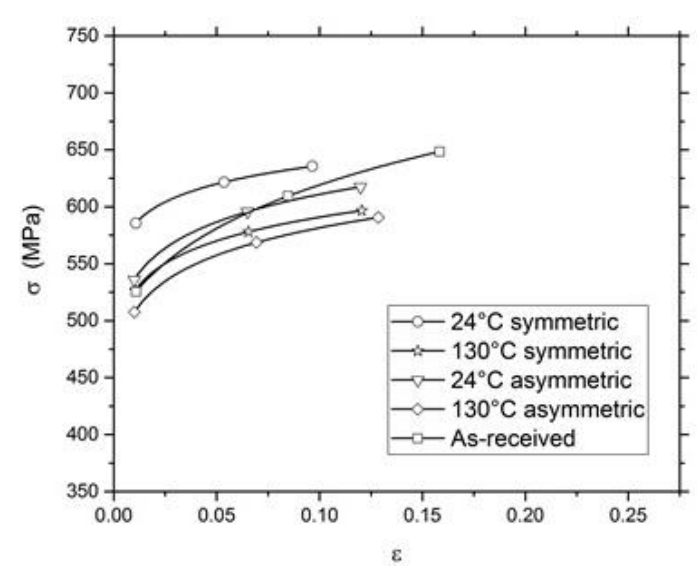

(b)

Figure 1: Plastic fitted curves from yield to ultimate stress of (a) T4 and (b) T651 specimens.

A qualitative visual comparison can be made observing the optical micrographs in Figures 2-5. There was not expressive grain changes or refinement between the as-received condition and the processed samples. Also, only a certain level of grain flattening was observed. 


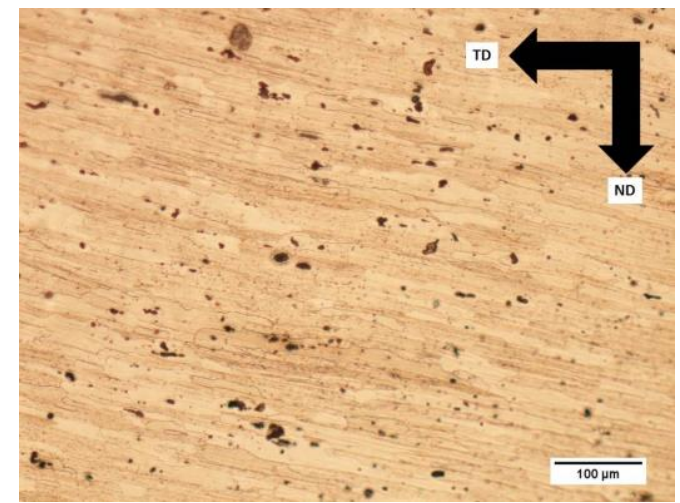

Figure 2: Micrograph of the as-received T651 condition.

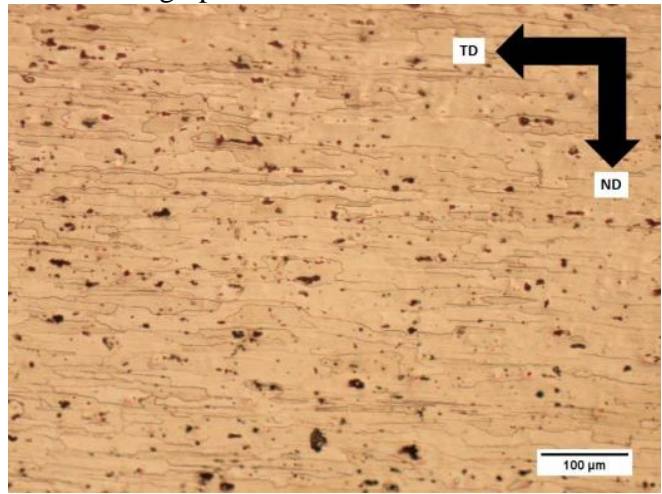

(a)

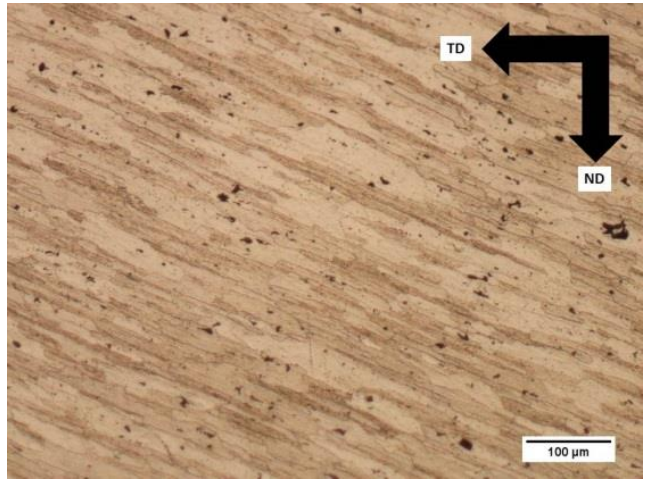

(b)

Figure 3: Micrograph of the $24^{\circ} \mathrm{C}$ symmetrically rolled (a) T4 and (b) T651 condition.

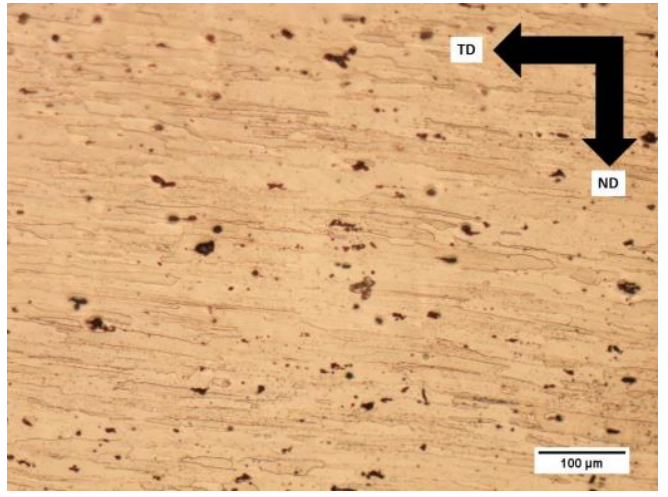

(a)

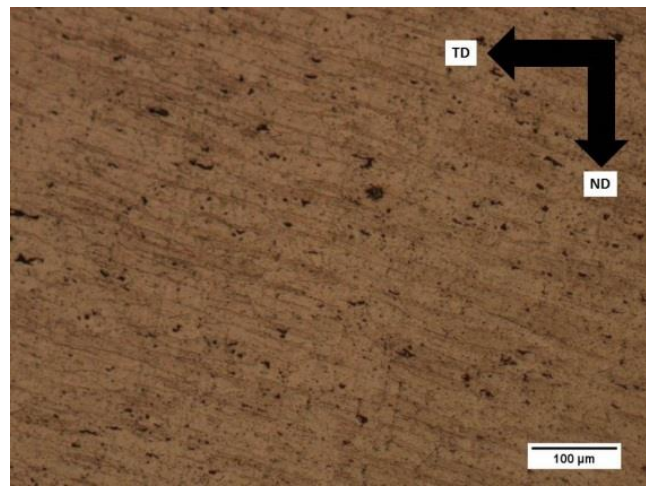

(b)

Figure 4: Micrograph of the $130^{\circ} \mathrm{C}$ symmetrically rolled (a) $\mathrm{T} 4$ and (b) $\mathrm{T} 651$ condition.

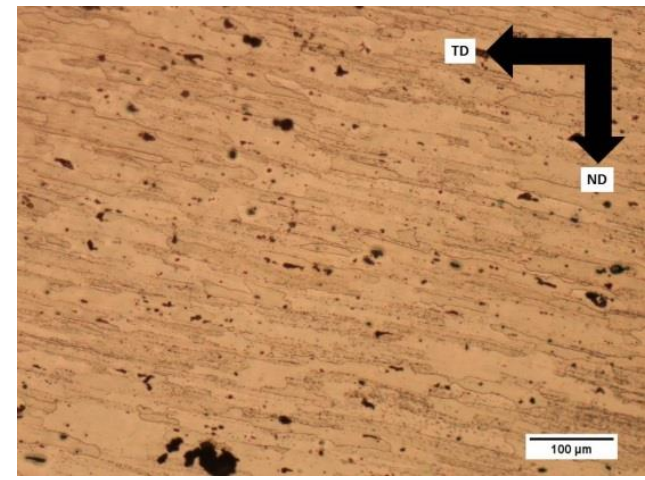

(a)

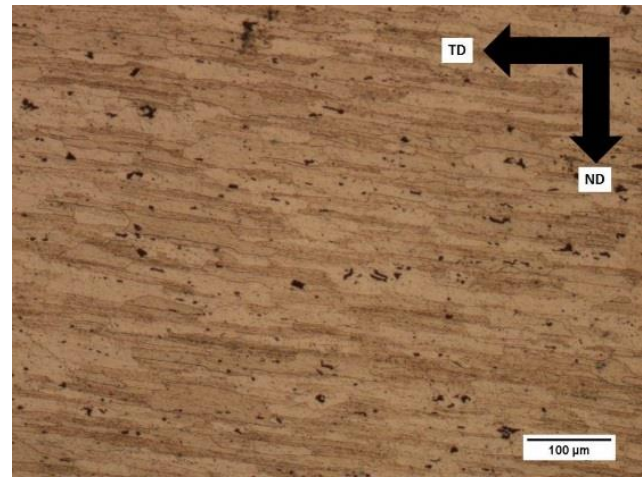

(b)

Figure 5: Micrograph of the $130^{\circ} \mathrm{C}$ asymmetrically rolled (a) $\mathrm{T} 4$ and (b) $\mathrm{T} 651$ condition. 
The presence of $\mathrm{MgZn}_{2}$ and CuMgAl precipitates was shown by SEM/EDS surface analysis. SEM analysis, presented in Fig. 6, shows rod shape precipitate in region 1, and round dots precipitates in region 2. The precipitate inside region 1 is $\mathrm{CuMgAl}$, and inside region 2, $\mathrm{MgZn}_{2}$ as seen in EDS spectrum results in Figs. $7 \mathrm{a}$ and $7 \mathrm{~b}$, respectively.

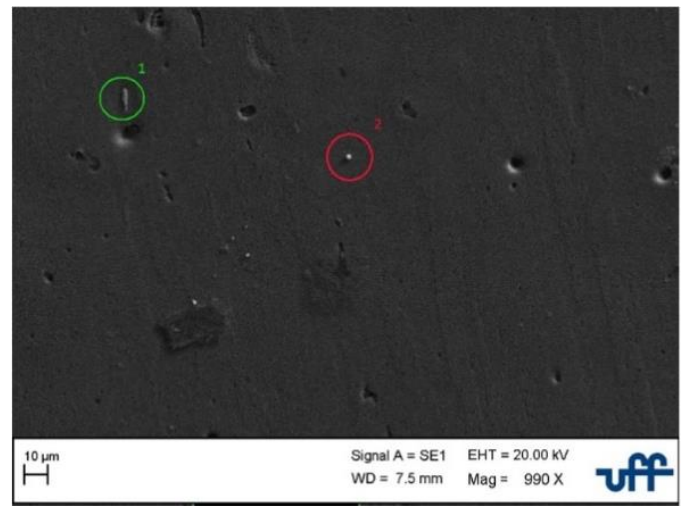

Figure 6: $\mathrm{SEM}$ micrograph showing the morphology of $\mathrm{CuMgAl}$ (region 1) and $\mathrm{MgZn}_{2}$ precipitates (region 2).

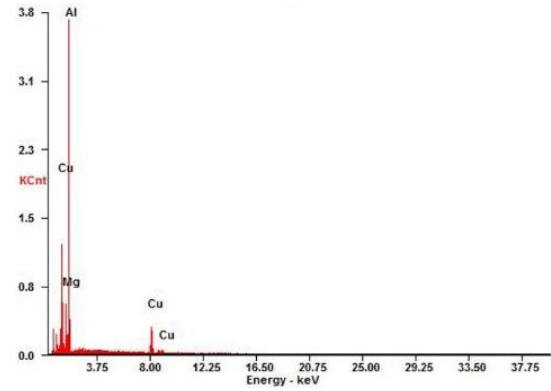

(a)

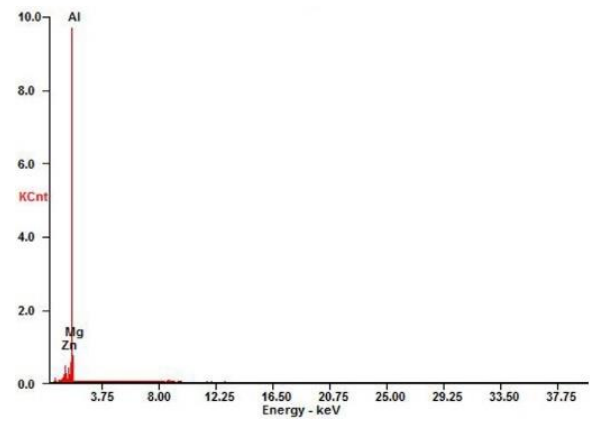

(b)

Figure 7: $\mathrm{EDS}$ results for (a) $\mathrm{CuMgAl}$ and (b) $\mathrm{MgZn}_{2}$ precipitates.

The warm rolled samples under T4 condition presented a bit higher difference on its plastic strengthening behavior. This fact can be explained by the presence and precipitation rate under the different rolling processes. Figure 8 shows the distribution of precipitates after rolling. In symmetrical rolling, see Fig. 8a, there is higher precipitate density (white dots) along the matrix than in asymmetrical rolling, as presented in Fig. 8b. This case matches with the mechanical results of plastic strengthening.

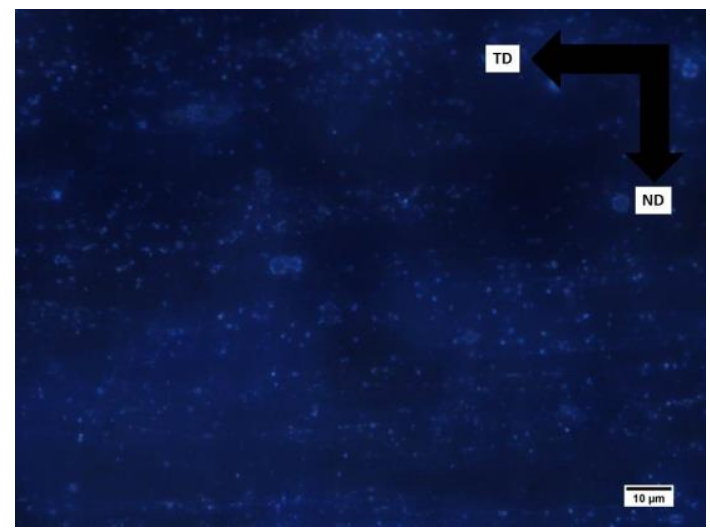

(a)

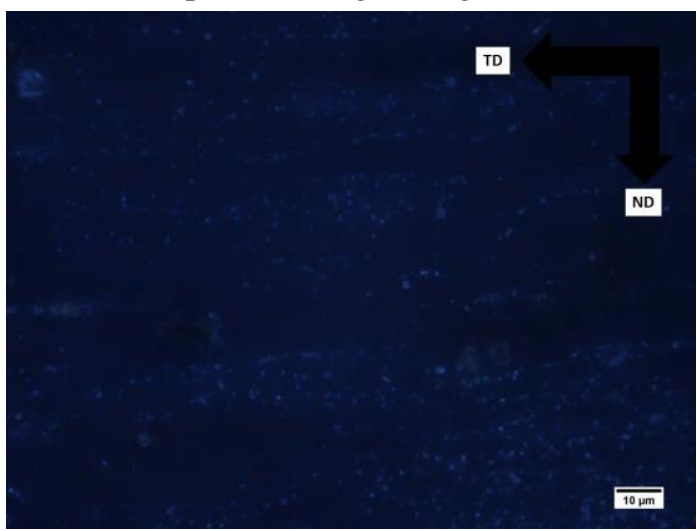

(b)

Figure 8: Polarized light micrographs of surface distribution of precipitates on T4 (a) symmetrically warm rolled and (b) asymmetrically warm rolled. 


\section{CONCLUSIONS}

In this present work, experimental analysis of mechanical behavior of an Al 7075 alloy after T651 and T4 heat treatments were performed by conventional and asymmetric rolling techniques at $24^{\circ} \mathrm{C}$ and $130^{\circ} \mathrm{C}$, and analyzed via uniaxial tensile test and microhardness Vickers.

The investigated alloy presented more expressive results under the combination of temperature and mechanical effects in naturally aged samples.

In naturally aged specimens, the $\eta$ phase precipitation had significant influence over the results, where $\mathrm{MgZn}_{2}$ and $\mathrm{CuMgAl}$ become precipitates along the aluminum matrix causing a strengthening of the material while the dislocations can still moves allowing a greater plastic deformation. When this phenomenon happens associated with temperature the precipitation kinetics increases, improving strength and reducing elongation.

Asymmetrical rolling had a better yield strength weight, in this case, against symmetrical under temperature influence. In T651 warm rolled samples, the temperature caused a small softening process over the grains decreasing its strength. Samples rolled at room temperature had an increase of yield strengthening, making the process, probably, the main cause of the results on both rolling types.

The process of asymmetrical rolling physically modified the hardness of the samples close to the surfaces in contact with the working rolls, with higher hardness on the surface in contact with the smaller roll. No significant changes through the center were noticed. These facts show that the asymmetrical rolling worked properly, enough to change the mechanical properties of a naturally aged Al 7075 sample.

\section{ACKNOWLEDGEMENTS}

The authors would like to thank to Instituto Militar de Engenharia IME for the technical assistance and CAPES, CNPq and FAPERJ for the research grants. Also thanks to Centro de Tecnologia SENAI Solda Maracanã in the person of Dr. Monica Costa Rezende for the help with spectroscopy analyses.

\section{BIBLIOGRAPHY}

[1] BRIDGMAN, P.W.. "On Torsion Combined with Compression”, Journal of Applied Physics, v.14, n.6, pp. 273-83, 1943.

[2] BRIDGMAN, P.W. "The Effect of Hydrostatic Pressure on Plastic Flow under Shearing Stress", Journal of Applied Physics, v.17, n.8, pp.692-698, 1946.

[3] Biography, NOBEL MEDIA AB 2014.

http://www.nobelprize.org/nobel_prizes/physics/laureates/1946/bridgman-bio.html , accessed in 1 Dec, 2016

[4] ESTRIN, Y., VINOGRADOV, A. "Extreme grain refinement by severe plastic deformation: A wealth of challenging science", Acta Materialia, v.61, n.3, pp. 782-817, 2013.

[5] CEPEDA-JIMÉNEZ, C. M., GARCIA-INFANTA, J.M., et al., "Mechanical properties at room temperature of an $\mathrm{Al}-\mathrm{Zn}-\mathrm{Mg}-\mathrm{Cu}$ alloy processed by equal channel angular pressing", Journal of Alloys and Compounds, v. 509, n. 35, pp. 8649-8656, 9/1/2011.

[6] LUKÁC̆, P., TURBA, K., MALEK, P., et al., "Deformation behaviour of ultrafine-grained 7075 aluminium alloy", International Journal of Materials Research, v. 100, n. 6, pp. 847-850, 2009.

[7] KIM, H.-K., KIM, H.-W., et al., "High-formability Al alloy sheet produced by asymmetric rolling of strip-cast sheet”, Materials Science and Engineering: A, v. 574, pp. 31-36, 2013.

[8] KIM, W. J., LEE, J.B., KIM, W.Y., et al., "Microstructure and mechanical properties of Mg-Al-Zn alloy sheets severely deformed by asymmetrical rolling", Scripta Materialia, v. 56, n. 4, pp. 309-312, 2007.

[9] JIANG, J., ZUO, Y.D.F., et al., "Mechanical properties and microstructures of ultrafine-grained pure aluminum by asymmetric rolling”, Scripta Materialia, v. 60, n. 10, pp. 905-908, 2009.

[10] WRONSKI, S., BACROIX, B.. "Microstructure evolution and grain refinement in asymmetrically rolled aluminium.”. Acta Materialia. v.76, pp.404-412, 2014.

[11] SIDOR, J. J., PETROV, R. H., KESTENS, L. A. I. "Microstructural and texture changes in severely deformed aluminum alloys", Materials Characterization, v. 62, n. 2, pp. 228-236, 2011. 
[12] MEYERS, M. A., MISHRA, A., BENSON, D. J. "Mechanical properties of nanocrystalline materials", Progress in Materials Science, v. 51, n. 4, pp. 427-556, 2006.

[13] VERLINDEN, B. "Severe plastic deformation of metals", Metalurgija, v. 11, n. 3, pp. 165-182, 2005.

[14] AZUSHIMA, A., KOPP, R., KORHONEN, A., et al., "Severe plastic deformation (SPD) processes for metals", CIRP Annals - Manufacturing Technology, v. 57, n. 2, pp. 716-735, 2008.

[15] LAPOVOK, R., TÓTH, L.S., WINKLER, M., et al., “A comparison of continuous SPD processes for improving the mechanical properties of aluminum alloy 6111", Journal of Materials Research, v.24, n.2, pp. 459-69, 2009.

[16] ISADARE, A.D, AREMO, B., ADEOYE, M.O., et al., "Effect of heat treatment on some mechanical properties of 7075 aluminium alloy”, Materials Research, v.16, pp. 190-194, 2013.

[17] HEALEY, J.T. Guinier-Preston zone evolution in 7075 Aluminum, Thesis of D.Sc., University of Florida, 1976.

[18] KIM, W.J., LEE J.B., KIM, W.Y., et al., "Microstructure and mechanical properties of Mg-Al-Zn alloy sheets severely deformed by asymmetrical rolling”, Scripta Materialia, v.56, n.4, pp. 309-312, 2007.

[19] JIANG, J., DING, Y., ZUO, F., SHAN, A.. "Mechanical properties and microstructures of ultrafinegrained pure aluminum by asymmetric rolling”, Scripta Materialia, v.60, n.10, pp. 905-908, 2009.

[20] DIETER, G.E.. Mechanical metallurgy, 3 ed, McGraw-Hill, 1986.

[21] ROUMINA R., SINCLAIR, C.W.. "Deformation Geometry and Through-Thickness Strain Gradients in Asymmetric Rolling”, Metallurgical and Materials Transactions A., v.39, n.10, pp. 2495-503, 2008.

[22] BOBOR, K., HEGEDUS, Z., GUBICZA, J., et al., "Microstructure and mechanical properties of Al 7075 alloy processed by differential speed rolling", Periodica Polytechnica, Mechanical Engineering, v.56, n.2, pp.111-115, 2012.

[23] Metals Handbook, v.2 - Properties and Selection: Nonferrous Alloys and Special-Purpose Materials, ASM International 10th Ed. 1990.

[24] Standard Test Methods for Tension Testing of Metallic Materials. ASTM International, 2015.

[25] Standard Test Method for Microindentation Hardness of Materials. ASTM International.

[26] ALMEIDA, D.S.S., MEDEIROS, N., MOREIRA, L.P., et al., “Análise Termomecânica de Rotas de Laminação a Quente da Liga de Mg AZ31”, In: Congresso Nacional de Engenharia Mecânica, Fortaleza, Ceará, 2016

\section{ORCID}

Neil de Medeiros

Matheus Garcia do Vale

Andersan dos Santos Paula

Luiz Paulo Mendonca Brandao

Saulo Brinco Diniz

Gláucio Soares da Fonseca https://orcid.org/0000-0002-8686-9529

https://orcid.org/0000-0002-2509-0298

https://orcid.org/0000-0002-0904-4240

https://orcid.org/0000-0002-2623-648X

https://orcid.org/0000-0003-4311-0173

https://orcid.org/0000-0001-9187-7956 